J. Clin. Chem. Clin. Biochem.

Vol. 20, 1982, pp. 705-712

\title{
Biochemical and Immunochemical Aspects of Carcinoembryonic Antigen (CEA) and CEA Related Antigens: \\ Current Status and Future Perspectives
}

By $C$. Wagener and $H$. Breuer $\dagger^{1}$ )

Institut für Klinische Biochemie, Universität Bonn, F. R. Germany

(Received June 22, 1981/May 14, 1982)

Summary: The carcinoembryonic antigen (CEA) is a glycoprotein which is defined mainly by its immunochemical properties. Essential biochemical properties of CEA are: its molecular weight of 180000-200000, the alkali stable bond of the oligosaccharide unit to the peptide (GlcNAc-Asn), and the solubility in $0.6-1.0 \mathrm{~mol} / 1$ perchloric acid. Most of the immunochemical and biochemical properties of CEA relate to preparations from liver metastases of colonic carcinomas. Biochemical heterogeneity of CEA preparations can be shown by several biochemical procedures e.g. isoelectric focussing, ion exchange chromatography and lectin affinity chromatography. CEA preparations that show differences with respect to biochemical parameters, but behave identically when immunochemical methods are applied, are called 'isomeric species' or 'isoantigens'.

Substances which react with anti-CEA sera but do not fulfill the criteria given for CEA are called 'CEA-related antigens'. The CEA-related antigens can be further subclassified into the cross reacting antigens, the membrane variant of CEA (CEA-M), and more or less well defined CEA related antigens which were isolated from sources different from colonic carcinoma or its liver metastases.

It is still controversial whether CEA is mainly a membrane glycoprotein or a secretory glycoprotein. The finding that additional antigenic determinants are present on a membrane variant of CEA suggests that a CEA precursor or a distinct CEA membrane variant may exist. CEA-M is only partially soluble in $0.6-0.9 \mathrm{~mol} / 1$ perchloric acid.

Many findings indicate that membrane glycoproteins from normal and tumour cells are glycosylated differently. It has been suggested that glycosylation of CEA and CEA related antigens may be organ or phase specific. As perchloric acid extraction is a generally used step in the isolation procedure of CEA, variants of CEA with a low perchloric acid solubility due to incomplete glycosylation may escape the isolation (e.g. CEA-M).

Recent results on the isolation of CEA variants from sources other than liver metastases of colonic carcinomas are contradictory. CEA-related antigens showing a close similarity to CEA, as well as CEA variants exhibiting considerable differences with respect to moleculär weight and perchloric acid solubility have been described.

Biochemische und immunchemische Aspekte dès carcinoembryonalen Antigens (CEA) und CEA-ähnlicher Antigene: Gegenwärtiger Stand und zukünftige Pẹrspeektiven

Zusammenfassung: Das carcinoembryonạe Antigen (CEA) ișt ein Glycoprotein, welches hauptsächlich durch seine immunchemischen Eigenschaften definiert ist. Charakteristische biochemische Eigenschaften von CEA sind das Molekulargewicht von 180000-200000, die alkalistabile Bindung der Oligosaccharid-Seitenketten an die Peptidkette -(GlcNAc-Asn) sowie die Löslichkeit in 0,6-1,0 mol/1 Perchlorsäure. Die immunchemischen und biochemischen Eigenschaften von CEA beziehen sich im allgemeinen auf Präparationen von Lebermetastasen primärer Coloncarcinome. CEA-Präparationen verhalten sich in Bezug auf verschiedene biochemische Kenngrößen heterogen, z.B. isoelektrischer Punkt, Lektinbindungseigenșchaften, Verhalten in der Ionenaustauscher-Chromatographie. CEAPräparationen, die sich auf Grund biochemischer Kenngrößen voneinander unterscheiden lassen, sich bei Anwendung immunchemischer Methoden jedoch identisch verhalten, werden als ,isomere Species' oder ,Isoantigene ' bezeichnet.

Substanzen, die mit Anti-CEA Seren reagieren, jedoch nicht die für CEA gegebenen Kriterien erfülen, werden als ,CEA-ähnliche Antigene' bezeichnet. CEA-ähnliche Antigene lassen sich weiter unterteilen in kreuzreagierende Antigene, die CEA-Membranvariante (CEA-M) sowie mehr oder weniger gut charakterisierte CEA-ähnliche Antigene, die aus anderen Geweben als Colon-Carcinomen bzw. deren Leber-Metastasen isoliert wurden.

1) Prof. Dr. H. Breuer, member of the Editorial Board of our journal, died August 20, 1982. 
Es ist noch nicht geklärt, ob CEA eher als ein Membranglycoprotein oder als ein sekretorisches Glycoprotein anzusehen ist. Der Befund, daß auf der Membranvariante von CEA zusätzliche antigene Determinanten nachweisbar sind, legt die Vermutung nahe, daß es sich um eine Vorstufe von CEA oder eine eigene CEA-Variante handelt. CEA-M ist nur partiell in 0,6-0,9 mol/1 Perchlorsäure löslich.

Tumorzellen unterscheiden sich von den entsprechenden Normalzellen in Bezug auf Vorkommen unḑ Glycosylierung von Membranglycoproteinen. Möglicherweise ist die Glycosylierung von CEA oder CEA-ähnlichen. Antigenen organoder phasenspezifisch. Durch die im Verlauf der CEA-Reinigung allgemein gebräuchliche Perchlorsäureextraktion werden möglicherweise perchlorsäurelabile CEA-Varianten mit einer unvollständigen Glycosylierung der Kohlenhydratseitenketten nicht erfaßt.

Neuere Ergebnisse über die Isolierung von CEA-ähnlichen Antigenen aus anderen Geweben ạ̣s Lebermetastasen yon Coloncarcinomen sind widersprüchlich. Es wurden sowohl Antigene, die konventionellen CEẠ-Präparationen ähnilich sind, als auch CEA-Varianten mit deutlichen Unterschieden in Molekulargewicht und Perchlorsäurelöslichkeit beschrieben.

\section{Introduction}

Carcinoembryonic antigen (CEA) ${ }^{1}$ is the most extensively studied human tumour marker. Since the first description of CEA in 1965, it became evident that CEA consists of a heterogenous population of isomeric species. Furthermore, cross reacting antigens, membrane variants and more or less organ specific CEA variants have been described. The relationship between the different members of the 'CEA family' has caused some confusions.

In the following review, an attempt is made to give a preliminary definition of CEA and CEA-related substances.

The biochemical properties of these substances are discussed on the basis of recent findings on the biosynthesis of glycoproteins in normal and neoplastic tissue.

\section{Diagnostic Use and Limitations of the Determination of CEA}

Carcinoembryonic antigen of man was first described in colonic carcinomas $(1,2)$ and first isolated from primary colonic carcinomas and their liver metastases $(3,4,5)$. As a result of the introduction of radioimmunological methods for the assay of CEA $(6,7,8)$, the use and limitations of CEA determinations for the diagnosis of malignant tumours have become apparent. The present stage of the application of the CEA determination for the diagnosis of cancer may be described as follows:

(a) High pretherapeutic CEA concentrations often indicate a poor prognosis of the patient (9).

\footnotetext{
1) Abbreviations:

$\mathrm{CEA}=$ carcinoembryonic antigen

NCA = normal cross reacting antigen

BGP-I = biliary glycoprotein I

CEA-M = membrane variant of CEA

GP-I = glycoprotein I
}

(b) The determination of CEA in serum before therapy of a malignant tumour and at regular intervals during the further course of the disease make it possible to. monitor the therapy and to detect tumour recurrence (i.e. local recurrence and/or distant metastäses) earlier than by other diagnostic means $(10,11,12)$.

(c) CEA-producing primary tumours and their metastases can be localized by immunoscintigraphy using radioactively labeled CEA specific antibodies (13).

The determination of CEA did not fulfill the hopes for an early and organ specific diagnosis of malignant tumours for the following reasons:

- Early tumour stages are rarely accompanied by elevàted CEA serum levels $(10,12,14)$.

- CEA in serum is also elevated in patients with various non-malignant diseases (15).

- Attempts to isolate organ-specific or tumour-specific CEA variants and to differentiate them from other CEA variants in serum or other body fluids have not yet been successful.

- According to the majority of the studies published, CEA does not evoke a cellular or humoral immune response in the autologous organism $(16,17,18)$.

- CEA determinations in serum or other body fluids are not suitable for screening studies (19).

\section{Possible Diagnostic and Therapeutic Applications of CEA in the Future}

Certain questions may be formulated concerning future research in the field of the clinical application of CEA:

(a) Is it possible to establish a tumour or organ specificity of the CEA assay by the isolation of CEA variants from tissues of different origin?

(b) Does a humoral or cellular immune response exist against 'species-specific' or cryptantigenic determinants on CEA or CEA related antigens (20)? 
(c) Is it possible to induce a humoral or cellular immune response against autologous tumour tissue by immunisation with chemically modified CEA preparations or CEA related substances?

(d)|Is it possible to make the chemotherapy of malignant tumours more specific by coupling chemotherapeutic agents to CEA-specific antibodies?

\section{Carcinoembryonic Antigen (CEA) and CEA-Related Substances: \\ Definition and Classification}

Despite intensive studies on the immunochemical and biochemical characterization of CEA, it is still difficult to give an exact definition of this glycoprotein. This may be explained as follows:

(a) CEA, like other glycoproteins, shows heterogeneity with respect to various biochemical parameters.

(b) A number of cross reacting antigens share common antigenic determinants with $\mathrm{CEA}$.

(c) An antigen has been described which shows immunological identity with CEA when analysed by anti-CEA sera. However, antisera which are induced against the antigen itself react with additional determinants in comparison with conventional CEA preparations.

\section{Definition of the carcinoem bryonic antigen}

The following definition of carcinoembryonic antigen takes into account the immunochemical properties, the tissues in which the antigen has first been described and from which it has been purified, the solubility in perchloric acid as well as some of the biochemical properties of the molecule. In the first description $(1,2)$, antisera directed against saline extracts from pooled primary colonic carcinomas and absorbed against saline extracts from pooled normal colonic tissue were tested against colonic carcinoma extracts by immunodiffusion, immunoelectrophoresis and other immunological techniques. Using these methods, two "tumourspecific' and two 'tumour-asssociated' antigens were detected. Consequently, the first papers of Gold and co-workers refer to 'carcinoembryonic antigens'. During the first purification of CEA $(3,4)$, the purification procedure was monitored by the antisera described by Gold \& Freedman $(1,2)$. These antisera were not monospecific. The purification procedure described by Krupey et al. $(3,4)$ involved the extraction of the tissue homogenate in $0.6 \mathrm{~mol} / 1$ perchloric acid, a paper-block electrophoresis, and a gel chromatography on SephadexG-200. According to Coligan et al. (5), the electrophoretic purification step may be omitted since it has no significant effect. Therefore, it may be concluded that the antigens described in the first publications of Gold $\&$ Freedman $(1,2)$ were separated from each other due to differences in either molecular weight or perchloric acid solubility. Probably, both assumptions are correct.

(1) The perchloric acid soluble cross reacting antigen NCA (normal cross reacting antigen (21)) which, as CEA, is present in colonic carcinomas in high concentrations and which shows the same electrophoretic mobility as CEA, can be separated from CEA by gel filtration.

(2) According to recent studies a further CEA-related antigen may be extracted from colonic carcinoma tissue by the use of water, saline or detergents $(20$, 22-25). The antigen does not seem to be identical with the known cross reacting antigens as it is less soluble in perchloric acid $(20,22-25)$ and it exhibits a molecular weight in the range of conventional CEA preparations $(200000$ daltons $(22,25))$. The purity of CEA preparations is checked by immunochemical and biochemical methods. In immunelectrophoresis, purified CEA gives a single precipitation line against antisera which have been induced with crude perchloric acid extracts from colonic carcinomas. Analytical ultracentrifugation reveals a single peák in purified CEA preparations $(3,4)$.

The perchloric acid solubility of CEA is due to its high carbohydrate content $(26,27)$. The oligosaccharide side chains are linked to the peptide by an alkali-stable $\mathrm{N}$-glycosidic bond between $\mathrm{N}$-acetylglucosamine and asparagine $(26,27)$.

Some criteria which must be fulfilled if a glycoprotein is to be designated as carcinoembryonic antigen (CEA) are listed below:

(a) reaction with antisera directed against saline extracts of pooled primary colonic carcinomas and absorbed with saline extracts of pooled normal colon using the methods described by Gold \& Freedman (1).

(b) solubility in $0.6-1.0 \mathrm{~mol} / 1$ perchloric acid.

(c) N-glycosidic linkage of the oligosaccharide side chains to asparagine.

(d) molecular weight of 180000-200000 daltons.

(e) single precipitation line in the $\beta$-globulin range in immunoelectrophoresis using antisera against crude $0.6-1.0 \mathrm{~mol} / 1 \mathrm{perchloric}$ acid extracts from primary colonic carcinomas or liver metastases from primary colonic carcinomas, depending on the source of the CEA-preparation.

(f) single boundary in the analytical ultracentrifuge.

Generally, the biochemical properties of CEA refer to CEA preparations from liver metastases of colonic or rectal carcinomas (for reviews see 1.c. $(28,29)$ ). The amino acid composition as well as the sequence of the $31 \mathrm{~N}$-terminal amino acids of CEA preparations from liver metastases of different individuals are remarkably 
stable $(28,30)$. This is not true for the carbohydrate composition (28). The differences in the carbohydrate composition of different CEA preparations are probably the main reason for the heterogeneic behaviour of different CEA preparations in isoelectric focussing (31), ion exchange chromatography (32) and lectin binding $(33,34)$. According to Gottschalk (see 35 ), biochemical heterogeneity of glycoproteins implies statistically significant differences between the distributions of the respective biochemical parameters. In this context, it should be mentioned that according to some investigators, the carbohydrate moiety of CEA may be altered by treatment with perchloric acid (24).

CEA preparations that show statistically significant differences with respect to biochemical parameters but behave identically when immunochemical methods are applied, are called 'isomeric species' (e.g. CEA-S (36)) or 'isoantigens' (37).

\section{CEA-related antigens}

In the following, antigens which react with anti-CEA sera but do not fulfill the criteria given for CEA, are designated 'CEA related antigens'.

\section{Cross reacting antigens}

Cross reacting antigens show a pattern of partial immunochemical identity with CEA in double diffusion or equilibrium radioimmunoassays when non-absorbed anti-CEA sera are used. Cross reacting antigens may reveal antigenic determinants which are not present in CEA (e.g. NCA ${ }^{1}$ ) (21), BGP-I ${ }^{1}$ ) (38)). In this context it should be mentioned that the specificity of the antisera which have been induced against the same immunogen in different animals of the same or different species may differ considerably (39). Furthermore, the reactivity of an antiserum in immunodiffusion may be different from that in radioimmunoassay $(40,41)$. For recent reviews on immunochemical and biochemical properties of cross reacting antigens see $(42,43)$.

\section{Membrane variant of CEA (CEA-M)}

Leung et al. (20) isolated a glycoprotein from crude membrane fractions of liver metastases of colonic carcinomas using sodium dodecyl sulfate (SDS). In immunodiffusion and radioimmunoassay, the antigen behaved qualitatively as CEA when anti-CEA sera were applied. However, antisera which were induced against the membrane variant reacted with antigenic determinants which were not present in conventional CEA preparations. The membrane variant is only partially soluble in $0.6 \mathrm{~mol} / 1$ perchloric acid. For these reasons, the membrane antigen is a distinct CEA related antigen which, according to the definition given above, differs from the cross reacting antigens. The membrane antigen has been designated 'CEA-M'. The molecular weight of CEA-M is similar to that of CEA. Preliminary results indicate that antisera against peptides resulting from the chemical cleavage of CEA-M seem promising for the development of a specific radioimmunoassay for gastrointestinal tumours (23).

\section{$C E A$ and $C E A$-related substances in water or saline extracts of primary colonic carcinomas and/or their liver metastases}

Different investigators have demonstrated two precipitation lines in immunodiffusion when water or saline extracts from primary colonic carcinomas and/or their liver metastases are tested against different antisera; these antisera were raised against the following different CEA or CEA-related antigen preparations:

(a) a fraction from a conventional CEA preparation with a low affinity to concanavalin-A $(24,34)$.

(b) a preparation, partially purified from saline extracts of.liver metastases of colonic carcinomas by Sepharose 4B and Sephadex G200 gel filtration, with a low affinity to concanavalin-A (monitoring of CEA positive fractions by a CEA specific radioimmunoassay (25)).

(c) a preparation partially purified from an ultrasonicated homogenate of a liver metastasis of a colonic carcinoma by ion exchange, concanavalin-A, Sepharose 4B and Sephadex G200 chromatography (monitoring of the CEA positive fractions by a CEA specific radioimmunoassay (22)).

The identity of the antigens described by the different investigators has not yet been established.

The antigen in the second precipitation line does not seem to be identical with the known cross reacting antigens, as it is only partially soluble in perchloric acid (22-25) and the molecular weight is about 200000 daltons (25). Furthermore, one of the antisera described was extensively absorbed by extracts from normal colonic mucosa, liver and spleen (34).

It cannot be excluded that the second precipitation line described above is due to an artefact, resulting from dimerization or polymerization of the antigens, which may lead to a masking of some of the antigenic determinants (44). Alternatively, one of the two antigens may be identical with CEA-M (20). However, the second precipitation line may also be related to a distinct CEA variant different from the CEA-related antigens mentioned șo far.

\section{$C E A$-related substances in carcinomas other than colorectal cancer}

Reçent investigations indicate that CEA-related sub-stances isolated from mammary carcinomas differ from colorectal CEA preparations both immunochemically 
and biochemically. To date, the results regarding biochemical properties, e.g. molecular weight, as well as immunochemical properties are contradictory $(45-47)$. Purified CEA related antigens from the cyst fluid from cystadenocarcinomas of the ovary exhibit the same molecular weight as CEA; however, only about $10 \%$ of a given preparation is soluble in perchloric acid (48). These results are in contradiction to the studies of Chism et al. (46) who described perchloric acidsoluble antigens in both cystadenocarcinomas of the ovary and mammary carcinomas with a molecular weight significantly lower than that of CEA. The molecular weight of CEA-related substances which were isolated from culture fluids of prostatic cancer cells was significantly higher than the molecular weight of conventional CEA preparations (49). CEA preparations from carcinomas of the bladder showed great similarities to CEA preparations from colonic carcinomas (50).

\section{Degradation products}

It cannot be excluded that due to intratumoural proteolytic cleavage or due to cleavage during the isolation procedure, cryptantigenic determinants are exposed in the degradation products of CEA. These degradation products may mimic CEA-related antigens with their own distinct antigenic determinants $(51,52)$.

\section{CEA and CEA-Related Antigens: \\ Biochemical Considerations}

In the following, the biochemical and immunochemical properties of CEA and CEA-related antigens are discussed in the context of the biosynthesis of glycoproteins in normal and neoplastic tissues.

\section{Is CEA a membrane-bound or a secretory glycoprotein?}

Immunohistochemical investigations using light microscopy showed that in colorectal carcinomas, CEA is localized in the apical cell membranes of the tumour cells bordering the glandular lumina $(53,54)$. According to electron microscopic studies, $\mathrm{CEA}$ is a component of the glycocalyx (55). The finding that in colonic carcinoma cells, CEA exhibits a marked cytoplasmic localization similar to secretory glycoproteins (56), has not been confirmed. According to our results, a cytoplasmic localization of CEA is found in crypt cells which are adjacent to carcinomas as well as in ulcerative colitis specimens (57). In specimens of linitis plastica, signet ring cells show a marked cytoplasmic localization of CEA (54). In medullary carcinomas of the thyroid gland, CEA is a component of the cell membranes bordering the lumina of the tumour glands, as well as a typical secretion product, showing an intracytoplasmic and pericellular localization (58).

CEA or CEA-related antigens are present in various body fluids (e.g. cyst fluid of mammary cysts (59); urine (60)) and in normal colon washings (61). According to our investigations, membrane-bound CEA seems to be released into the blood stream from necrotic colonic carcinoma tissue (14). GP-I ${ }^{1}$ ) (62), which is similar to or identical with CEA, is tightly bound in the cell membranes of cultivated colonic carcinoma cells. The same finding applies to $\operatorname{CEA}-\mathrm{M}(20,23)$.

Biosyn thesis of glycoproteins with an alkalistable linkage of the carbohydrate side chains to asparagine

CEA belongs to the class of glycoproteins in which the carbohydrate side chains are linked to asparagine via $\mathrm{N}$-acetylglucosamine $(26,27)$. The $\mathrm{N}$-glycosidic bond is stable against mild alkali. In recent years, important progress towards the understanding of the biosynthesis of this class of glycoproteins has been made.

The biosynthesis of the oligosaccharide side chains begins with the formation of oligosaccharidedolicholphosphate. This oligosaccharide-lipid molecule contains the so-called 'core' oligosaccharides of the glycoprotein. During the synthesis of the peptide chain, the oligosaccharide unit is transferred to asparagine when an Asn-X-Ser/Thr-tripeptide sequence has been translated and is oriented so that it can interact with both the substrate oligosaccharide-P-P-dolichol and the membrane associated oligosaccharide transferase $(63,44)$. Before the glycosylation of the glycoprotein is continued, additional glucosyl and mannosyl residues are clipped $(65,66)$. Both membrane and secretory glycoproteins seem to be closely associated to the membrane of the rough endoplasmic reticulum as long as the oligosaccharides are transferred from the oligosaccharide-lipid to the peptide (64). When the synthesis of the peptide chain and the assembly of the oligosaccharide chains are terminated, glycosylation of the 'complex' glycoproteins continues in the Golgi apparatus (67). Whereas membrane glycoproteins remain membrane-bound during the whole process of glycosylation due to a hydrophobic sequence near the C-terminal end of the peptide chain, secretory proteins remain membrane-associated only until translation is terminated (64).

Many of the results cited above suggest that CEA and CEA-related antigens show characteristics of membranebound as well as secretory glycoproteins. If this assumption is correct, there should be differences in the structure and antigenicity of secretory and membrane-bound CEA variants. The results of Leung et al. (20) point in this direction. 
Glycosylation of membrane glycoproteins in tumour cells compared to the corresponding normal cells

Studies on differences between normal and malignant cells regarding the occurrence and structure of membrane glycoproteins are contradictory. Some investigators found a higher percentage of sialoglycopeptides in the membrane fractions of transformed cells as compared with the corresponding normal cells $(68-70)$. Other investigators found an incomplete glycosylation of membrane-bound glycoproteins in tumour cells $(71-73)$. It has been suggested that the cell membranes of foetal and tumour cells are characterized by an incomplete glycosylation of glycoproteins accompanied by the exposure of galactosyl transferases on the cell membranes (74-76). Kim et al. found a lower content of carbohydrates in the membrane glycoproteins of colonic adenocarcinomas as compared with normal colonic mucosa. The content of galactosamine, fucose and sialic acid was significantly reduced (77). Considering the investigations cited above, it seems possible that a different degree of glycosylation may be found in CEA from normal and neoplastic tissue. This hypothesis is supported by the findings of Rogers et al. (78) who described differences in the lectin binding of CEA preparations from normal colon and from colonic carcinomas.

Organ and phase specificity of the biosynthesis of glycoproteins

The carbohydrate composition of glycoproteins is not directly controlled by the base sequence of the DNA. However, this does not imply that the so-called microheterogeneity of glycoproteins, which is due to differences in the carbohydrate composition, is random. It has been shown that the nonrandom attachment of various terminal sugars in the complex-type oligosaccharides may be related to the fact that the glycosyltransferases responsible for the addition of the respective sugars have specificity requirements that go beyond the acceptor sugar residue to encompass other structural features on the oligosaccharide $(79,80)$.

The concanavalin-A binding of $\alpha$-foetoprotein produced in the yolk sac is different from that of liver $\alpha$-foetoprotein (81). CEA-related antigens from cancer of the breast and ovary showed a lower binding to concanavalin-A than the corresponding CEA related antigens in colorectal carcinomas (46). According to Rule and coworkers, the biochemical heterogeneity of CEA is due to a phase specificity of gene expression (82).

\section{Conclusion}

Carcinoembryonic antigen (CEA) is mainly defined by its immunochemical properties. Essential biochemical characteristics of CEA are its molecular weight of 180000-200000 daltons, the $\mathrm{N}$-glycosidic linkage of the oligosaccharide units between $\mathrm{N}$-acetylglucosamine and asparagine, and its solubility in $0.6-1.0 \mathrm{~mol} / 1$ perchloric acid. The amino acid composition and, as far as analysed, the sequence of the $24 \mathrm{~N}$-terminal amino acids are remarkably stable in liver metastases of colonic carcinomas from different individuals as well as in normal colon washings (28). CEA is composed of a single polypeptide chain. These findings lead to the assumption that the amino acid sequence of $\mathrm{CEA}$ is determined by a single gene which shows great stability in different individuals as well as in normal and neoplastic colonic tissues.

In contrast, the carbohydrate composition of different CEA preparations is heterogenous. On the one hand, this may be due to a partial degradation of the oligosaccharide side chains during tumour necrosis. On the other hand, this heterogeneity may be traced back to a phase or organ specificity in the biosynthesis of the carbohydrate moiety of CEA.

In water and saline extracts as well as in the membrane fraction of colonic carcinomas and/or their liver metastases, a CEA-related perchloric acid lable antigen is present, providing the possibility of an artefact due to aggregation phenomena is excluded. This CEA-related antigen may be either a CEA precursor or a membrane variant different from CEA. The partial perchloric acid insolubility of the variant may be due to the membrane associated part of the molecule and/or to an incomplete glycosylation. When an antiserum is induced against the variant some antibody populations may possibly be directed against the membrane-associated portion of the molecule.

One might speculate that during tumour progression antigenic determinants of membrane-bound CEA variants which are normally covered in the cell membrane become exposed thus stimulating the autologous immune system.

The cross reacting antigens differ from CEA in their amino acid composition and, as far as analysed, in the sequence of the $24 \mathrm{~N}$-terminal amino ácids (20). CEA and $\mathrm{NCA}^{1}$ ) are present in the same cells of colonic carcinomas (54). Therefore, the synthesis of CEA and $\left.\mathrm{NCA}^{1}\right)$ is probably coded by different genes.

The available data règarding the isolation and characterization of CEA-related substances from non-colonic carcinomas are contradictory. The high molecular weight of the prostatic CEA variant suggests a genetically determined difference of the protein moiety in,comparison with colorectal CEA preparations. The low perchloric acid solubility of the CEA variant present in the cyst fluid of cystadenocarcinomas of the ovary may indicate an organ-specific biosynthesis of the oligosaccharide side chains. 
In recent years, many efforts have been made to improve the organ and tumour specificity of the CEA determination. This aim has not been achieved as yet. However, some of the findings discussed here indicate that progress may be possible by the isolation and characterization of
CEA and CEA-related antigens from different cell fractions' of tumours of different origin, using methods that avoid the harsh perchloric acid extraction of the tissue.

\section{References}

1. Gold, P. \& Freedman, S. O. (1965) J. Exp. Med. 121, 439-462.

2. Gold, P. \& Freedman, S. O. (1965) J. Exp. Med. 122, $467-481$.

3. Krupey, J., Gold, P. \& Freedman, S. O. (1967) Nature 215, 67-68.

4. Krupey, J., Gold, P. \& Freedman, S. O. (1968) J. Exp. Med. $128,387-398$.

5. Coligan, J. E., Lautenschleger, J. T., Egan, M. L. \& Todd, C. W. (1972) Immunochemistry 9, 377-386.

6. Thomson, D. M., Krupey, J., Freedman, S. O. \& Gold, P. (1969) Proc. Natl. Acad. Sci. USA 64, 161-167.

7. Hansen, H. J., Lance, K. P. \& Krupey, J. (1971) Clin. Res. $19,143$.

8. Egan, M. L., Lautenschleger, J. T., Coligan, J.E. \& Todd, C. W. (1972) Immunochemistry 9, 289-299.

9. Chu, T. M., Lavin, P., Day, J., Evans, J. T., Mittleman, A., Holyoke, E. D. \& Vincent, R. (1979) in: Carcino-Embryonic Proteins, vol. I (Lehmann, F. G., ed.), 55-64, Elsevier/ North Holland Biomedical Press, Amsterdam, New York, Oxford.

10. Dhar, P., Moore, T., Zamcheck, N. \& Kupchik, H. Z. (1972) J. Am. Med. Assoc. 221, 31-35.

11. Sugarbaker, P. H., Zamcheck, N. \& Moore, F. D. (1976) Cancer 38, 2310-2315.

12. Myers, R. E., Sutherland, D. J., Kellen, J. A., Malkin, D. G. \& Malkin, A. (1978) Cancer 42, 1520-1526.

13. Goldenberg, D. M., DeLand, F., Kim, E., Bennett, S., Primus, F. J., van Nagell, J. R., Estes, N., DeSimone, P. \& Rayburn, P. (1978) N. Engl. J. Med. 298, 1384-1388.

14. Wagener, C., Müller-Wallraf, R., Nissen, S., Gröner, J. \& Breuer, J. (1981) J. Natl. Cancer Inst. 67, 539-547.

15. Hansen, H. J., Snyder, J. J., Miller, E., Vandevoorde, J. P., Neal Miller, O., Hines, L. R. \& Burns, J. J. (1974) Human Pathol. 5, 139-147.

16. Lejtenyi, C., Freedman, S. O. \& Gold, P. (1971) Canceri 28, $115-120$.

17. Collatz, E., von Kleist, S. \& Burtin, P. (1971) Int. J. Cancer 8, 298-303.

18. Lo Gerfo, P., Herter, F. P. \& Bennett, S. J. (1972) İnt. J. Cancer 9, 344-348.

19. Mackay, I. R. (1979) in: Immunodiagnosis of Cancer, vol. I (Herberman, R. B. \& McIntire, K. R., eds.), 255-264, Marcel Dekker, New York, Basel.

20. Leung, J. P., Plow, E. F., Eshdat, Y., Marchesi, V. T. \& Edgington, T. S. (1977) J. Immunol, 119, 271-276.

21. Von Kleist, S., Chavanel, G. \& Burrtin, P. (1972) Proc. Natl. Acad. Sci. USA 69, 2492-2494.

22. Carrico, R. J. \& Úsategui-Gomez, M. (1975) Cancer Res. 35, 2928-2934.

23. Leung, J. P., Eshdat, Y. \& Marchesi, V. T. (1977) J. Immunol. $119,664-670$.

24. Keep, P. A., Leake, B. A. \& Rogers, G. T. (1978) Brit. J. Cancer 37, 171-182.

25. Coligan, J. E. \& Slayter, H. S. (1979) Mol. Immunol. 16, 129-135.

26. Coligan, J. E. \& Todd, C. W. (1975) Biochemistry 14, $805-810$.

27. Hammarström, S., Engvall, E., Johansson, B. G., Svensson, S., Sundblad, G. \& Goldstein, I. J. (1975) Proc. Natl. Acad. Sci. USA 72, 1528-1532.

28. Shively, J. E. \& Todd, C. W. (1978) Scand. J. Immunol. 7, Suppl. 6, 19-31.

29. Pritchard, D. G. \& Todd, C. W. (1979) in: Immunodiagnosis of Cancer, vol. I (Herberman, R. B. \& McIntire, K. R., eds.), 165-180, Marcel Dekker, New York, Basel.

30. Terry, W. D., Henkart, P. A., Coligan, J. E. \& Todd, C. W. (1974) Transplant. Rev. 20, 100-129.

31. Coligan, J.E., Henkart, P. A., Todd, C. W. \& Terry, W. D. (1973) Immunochemistry 10, 591-599.

32. Eveleigh, J. W. (1974) Cancer Res. 34, 2122-2124.

33. Harvey, S. R. \& Chu, T. M. (1975) Cancer Res. 35, $3001-3008$

34. Rogers, G. T., Searle, F. \& Wass, M. (1975) Immunochemistry $12,839-842$.

35. Gottschalk, A. (ed.) (1972) Gly coproteins. Elsevier/North Holland Biomedical Press, Amsterdam, New York, Oxford.

36. Plow, E. F. \& Edgington, T. S. (1975) Int. J. Cancer 15, $748-761$.

37. Mach, J.-P. (1976) in: Onco-Developmental Gene Expression (Fishman, W. \& Sell, S., eds.), 557,-558, Academic Press, New York, San Francisco, London.

38. Svenberg, T. (1976) Int. J. Cancer 17, 588-596.

39. Tomita, J. T., Safford, J. W. \& Hirata, A. A. (1974) Immunology 26, 291-298.

40. Primus, F. J., Newman, E. S. \& Hansen, H. J. (1977) J. Immunol. 118, 55-61.

41. Engvall, E., Shively, J. E. \& Wrann, M. (1978) Proc. Natl. Acad. Sci. USA 75, 1670-1674.

42. Von Kleist, S. (1979) in: Carcino-Embryonic Proteins, vol. I (Lehmann, F. G., ed.), 35-39, Elsevier/North Holland Biomedical Press, Amsterdam, New York, Oxford.

43. Von Kleist, S. (1979) in: Immunodiagnosis of Cancer, vol. I (Herberman, R. B. \& McIntire, K. R., eds.), 322-342, Marcel Dekker, New York, Basel.

44. Kleinman, M. S., Harwell, L. \& Turner, M. D. (1971) Gut $12,1-10$.

45. Kuo, T., Rosai, J. \& Tillack, T. W. (1973) Int. J. Cancer 12, $532-542$.

46. Chism, S. E., Warner, N. L., Wells, J. V., Crewther, P., Hunt, S., Marchalonis, J. J. \& Fudenberg, H. H. (1977) Cancer Res. 37, 3100-3108.

47. Santen, R. J., Collette, J. \& Franchimont, P. (1980) Cancer Res. 40, 1181-1188.

48. Yamashita, K., Aitio, M.-L. \& Dawson, J. R. (1979) Cancer Res. 39, 1760-1765.

49. Williams, R. D., Bronson, D. L., Myl, A. D., Vandevoorde, J. P. \& Elliott, A. (1979) Cancer Res. 39, 2447-2450.

50. Zimmerman, R. \& Hammarström, S. (1978) Urol. Res. 6 , 215-219.

51. Wolberg, G., Liu, C. T. \& Adler, F. L. (1970) J. Immunol. 105, 797-801.

52. Plow, E: F. \& Edgington, T. S. (1973) J. Clin. Invest. 52, 273-282.

53. Gold, P., Gold, M. \& Freedman, S. O. (1968) Cancer Res. $28,1331-1334$

54. Burtin, P., von Kleist, S., Sabine, M. C. \& King, M. (1973) Cancer Res. 33, 3299-3305.

55. Gold, P., Krupey, J. \& Ansari, H. (1970) J. Natl. Cancer Inst. $45,219-225$.

56. Rogalsky, V. Y. (1975) J. Natl. Cancer Inst. 54, 1061-1071.

57. Wagener, C., Hain, F., Breuer, H., Olude, S., Cremer, H. \& Müller-Waliraf, R. (1981) Oncodevelopmental Biology and Medicine 2, 331-343.

58. Burtin, P., Calmettes, C. \& Fondaneche, M. C. (1979) Int. J. Cancer 23, 741-745. 
59. Fleisher, M., Oettgen, H. F., Breed, C. N., Robbins, G. F., Pinsky, C. M. \& Schwartz, M. K. (1974) Clin. Chem. 20, $41-42$.

60. Hall, R. R., Laurence, D. J., Darcy, D., Stevens, U., James, R., Roberts, S. \& Neville, A. M. (1972) Brit. Med. J. 3, 609-611.

61. Go, V. L., Ammon, H. V., Holtermuller, H., Krag, E. \& Phillips, S. F. (1975) Cancer 36, 2346-2350.

62. Tsao, D. \& Kim, Y.S. (1978) J. Biol. Chem. 253, $2271-2278$.

63. Lennarz, W. J. (1975) Science 188, 986-991.

64. Struck, D. K. \& Lennarz, W. J. (1980) in: The Biochemistry of Glycoproteins and Proteoglycans (Lennarz, W. J., ed.), 35-83, Plenum Press, New York, London.

65. Hunt, L. A., Etchișon, J. R. \& Summers, D. F. (1978) Proc. Natl. Acad. Sci. USA 75, 754-758.

66. Tabas, I., Schlesinger, S. \& Kornfeld, S. (1978) J. Biol. Chem. 253, 716-722.

67. Schachter, H. (1974) Biochem. Soc. Symp. 40, 57-71.

68. Warren, L., Fuhrer, J. P. \& Buck, C. A. (1972) Proc. Natl. Acad. Sci. USA 69, 1838-1842.

69. Van Beek, W. P., Smets, L. A. \& Emmelot, P. (1973) Cancer Res. 33, 2913-2922.
70. Van Beek, W: P., Emmelot, P. \& Homburg, C. (1977) Brit. J. Cancer 36, 157-165.

71. Wu, H. C., Meezañ, E., Black, P. H. \& Robbins, P. W. (1969) Biochemistry 8, 2509-2517.

72. Grimes, W. J. (1970) Biochemistry 9, 5083-5092.

73. Villarem, M. J., Jouanneau, J. \& Bourrillon, R. (1981) Biochem. Biophys: Res. Comm. 98, $7-14$.

74. Weiser, M. M. (1973) J. Biol. Chem. 248, 25136-2541.

75. Weiser, M. M. (1973) J. Biol. Chem. 248, 2542-2548.

76. Podolsky, D. K., Weiser, M. M. \& LaMont, J. T. (1974) Proc. Natl. Acad. Scị. USA 71, 904-908.

77. Kim, Y. S., Isaac, R. \& Perdomo, J. M. (1974) Proc. Natl. Acad. Sci. USA 71, 4869-4873.

78. Rogers, G. T. \& Keep, P. A. (1980) Eur. J. Cancer 16, $127-131$.

79. Benżinger, J. \& Kornfeld, S. (1974) J. Biol. Chem. 249, . 7260-7269.

80. Tai, T., Ito, S., Yamashita, K., Muramatsư, T. \& Kobata, A. (1975) Biochem. Biophys. Res. Comm. 65, 968-974.

81. Ruoslahti, E., Engvall, E., Pekkala, A. \& Sep̄pälä, M. (1978) Int. J. Cancer 22, 515-520.

82. Rule, A. H. \& Goleski-Reilly, C. (1974) Cancer Res. 34, 2083-2087.
Priv.-Doz. Dr. C. Wagener Institut für Klinische Biochemie Sigmund-Freud-Straße 25 D-5300 Bonn 1

F. R. Germany 